\title{
纳米磁粉固定化酶催化合成 $\boldsymbol{\alpha}-\mathrm{D}-$-葡萄糖-1-磷酸
}

\author{
董青，欧阳立明，刘建文，许建和 \\ 华东理工大学生物反应器工程国家重点实验室, 上海 200237
}

\begin{abstract}
摘要：建立了以麦芽糊精和磷酸盐为底物,在常温下合成 $\alpha-\mathrm{D}$-葡萄糖-1-磷酸的生物催化体系. 从大肠杆菌 K12 中克隆表达了麦 芽糊精磷酸化酶, 并固定化在氨基修饰的磁性纳米颗粒上, 以便于酶的回收和重复利用. 在优化的反应条件下,于 $200 \mathrm{ml}$ 体系中 连续使用该固定化酶 8 批次,催化合成了 $\alpha$-D - 葡萄糖-1-磷酸. 经过简单的纯化步骤, 最终得到 $440 \mathrm{mg}$ 产品, 分离产率为 $70.5 \%$. 关键词: $\alpha$-D-葡萄糖-1-磷酸; 麦芽糊精磷酸化酶; 麦芽糊精; 磁性纳米颗粒; 固定化生物催化剂 中图分类号: O643/Q55 文献标识码: A
\end{abstract}

\section{Efficient Synthesis of $\alpha$-D-Glucose-1-Phosphate by Maltodextrin Phosphorylase Immobilized on Amino-functionalized Magnetic Nanoparticles}

\author{
DONG Qing, OUYANG Liming, LIU Jianwen, XU Jianhe* \\ State Key Laboratory of Bioreactor Engineering, East China University of Science and Technology, Shanghai 200237, China
}

\begin{abstract}
D-Glucose-1-phosphate (Glc-1-P) is an expensive intermediate in the biosynthesis of nucleotide glucose. This paper describes a biocatalytic system for the efficient synthesis of Glc-1-P from the low cost raw materials: maltodextrin and phosphate at ordinary temperatures. After molecular cloning and the expression of a maltodextrin phosphorylase (MalPase) gene from E. coli (Escherichia coli) K12, the resultant recombinant enzyme was immobilized on amino-functionalized magnetic nanoparticles for recycling and repeated use. Conditions for the biocatalytic reaction were optimized and the immobilized MalPase could be easily recovered and reused over eight cycles in the repeated synthesis of Glc-1-P. After simple purification steps approximately $440 \mathrm{mg}$ of crude product was obtained with a moderate isolation yield of $70.5 \%$.
\end{abstract}

Key words: $\alpha$-D-Glucose-1-phosphate; maltodextrin phosphorylase; maltodextrin; magnetic nanoparticle; immobilized biocatalyst

Glycoconjugates have important roles in various types of cellular behavior including energy storage, cell wall structure, signaling, and cell-to-cell interactions [1] and, therefore, glycosylation is an important biological reaction. Glycosylation may also alter the biological activities of glycoside drugs significantly [2]. Carbohydrate-based drug discovery is currently a subject of great interest [3]. Glycosyl phosphates are important building blocks for the biosynthesis of nucleotide sugars, which can be used directly as glycosyl donors for glycosylation reactions catalyzed with different glycosyltransferases [4,5]. Glucose-1-phosphate is the most common phosphoactivated sugar and it can be synthesized through the isomerization of glucose-6-phosphate or galactose-1-phosphate in vivo. However, if isomerization is selected as the technique of choice for the synthesis of glucose-1-phosphate in vitro, the separation and purification of the product becomes rather difficult. Moreover, the use of glucose-6-phosphate or galactose-1-phosphate as a substrate for the production of the less expensive Glc-1-P is not economically feasible. Maltodextrin phosphorylase or $\alpha$-glucan phosphorylase (EC 2.4.1.1) catalyzes the synthesis of glucose-1-phosphate from $\alpha$-1,4-glucans such as starch and glycogen derived from bacteria, yeasts, animals, or plants [6]. Maltodextrin is a kind of soluble starch and is a cheap source of sugars, which can be used to derive proteins and produce glycoproteins [7]. The degradation of maltodextrin, which is cheaper than glucogen from animals has already been reported. The degradation involves the use of malto-

Received date: 26 March 2010.

*Corresponding author. Tel: +86-21-6425-2498; Fax: +86-21-6425-0840; E-mail: jianhexu@ecust.edu.cn

Foundation item: Supported by the National Natural Science Foundation of China (20773038, 20902023), the National Basic Research Program of China (973 Program, 2009CB724706, 2009ZX09501-016), the China National Special Fund for State Key Laboratory of Bioreactor Engineering (2060204), and the Shanghai Leading Academic Discipline Project (B505).

English edition available online at ScienceDirect (http://www.sciencedirect.com/science/journal/18722067). 


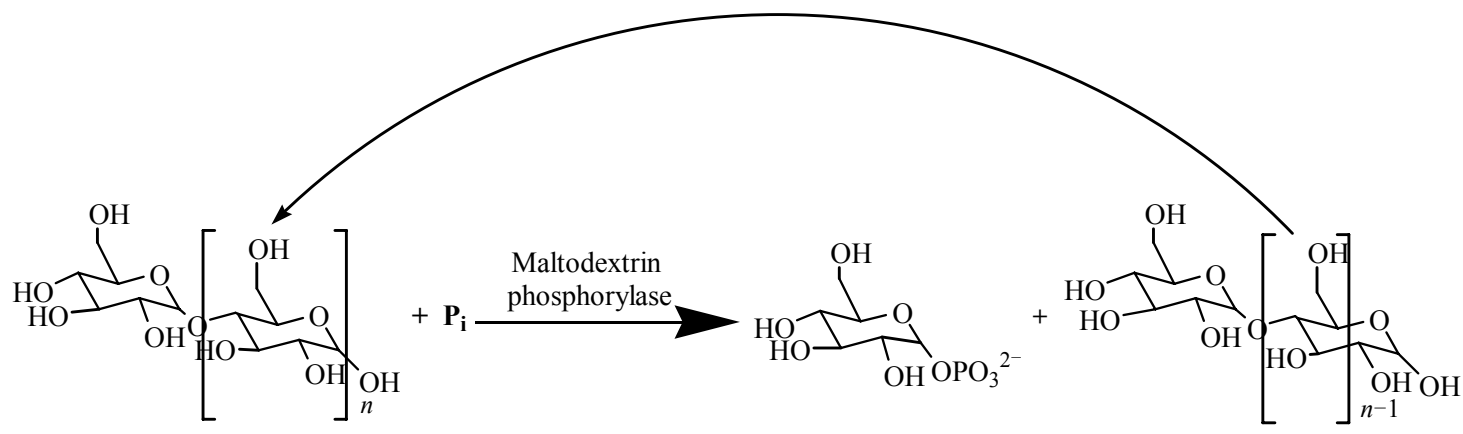

Scheme 1. Biosynthesis of $\alpha$-D-glucose-1-phosphate by maltodextrin phosphorylase from E. coli K12 immobilized on amino-functionalized magnetic nanoparticles.

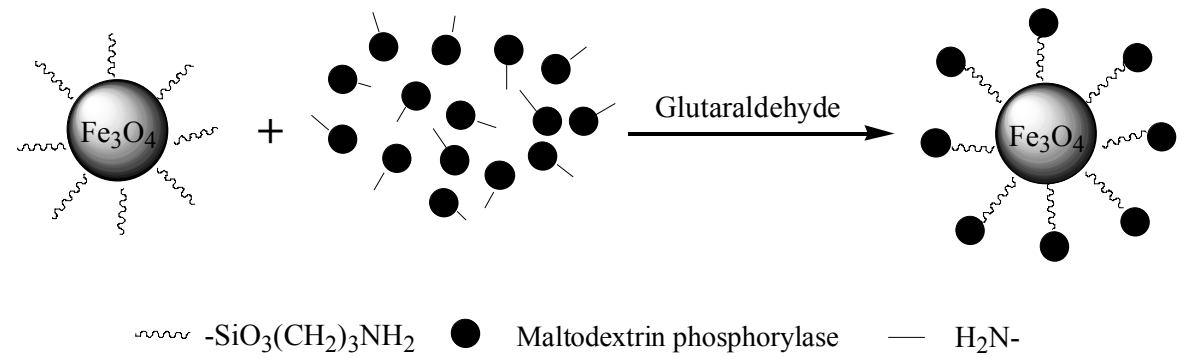

Scheme 2. Cross-linking between $\mathrm{Fe}_{3} \mathrm{O}_{4}$ nanoparticles and the enzyme.

dextrin phosphorylase (MalPase) to produce phosphoactivated glucose (Scheme 1) [8-10]. This can provide a more effective and economical method for producing high value-added Glc-1-P.

Although a MalPase-catalyzed reaction effectively catalyzes the synthesis of Glc-1-P from maltodextrin, all the components of the reaction system including the enzyme, substrates, and products are very water-soluble making product purification very complicated and not cost effective [11]. Immobilized enzymes are considered to be helpful in isolating protein biocatalysts from reaction mixtures. Thus, the overall cost of production may be reduced further because enzyme reusability improves after immobilization. We used amino-functionalized magnetic nanoparticles for this purpose in this study.

Amino-functionalized magnetic nanoparticles are a relatively new material for enzyme immobilization. They have several advantages that have attracted the attention of many researchers [12-15]. Treating $\mathrm{Fe}_{3} \mathrm{O}_{4}$ particles with $\mathrm{NaOH}$ results in the formation of a number of hydroxyl groups on its surface, which allows amine-functionalized magnetic particles to be produced by the chemical coating of 3 -aminopropyltriethoxysilane. With glutaraldehyde as the coupling reagent, amino groups on magnetic nanoparticles can react directly to generate aldehyde groups, which in turn will form Schiff bases with MalPase. The immobilization of enzymes onto amino-functionalized magnetic nanoparticles (Scheme 2) is a rapid process. These nanoparticles act as effective supports for immobilizing enzymes. More importantly, the immobilized enzyme can be easily separated from the reaction mixture and recycled through the simple application of a magnetic field. The low cost of fabrication of amino-functionalized magnetic nanoparticles (0.06 US\$/g) also makes this form of immobilization support promising for industrial-scale processes requiring enzymes. Although other materials have been used for immobilizing $\alpha$-glucan phosphorylase [16,17], there have been no reports regarding immobilization of MalPase onto amino-functionalized magnetic nanoparticles for the synthesis of glucose-1-phosphate. Therefore, amino-functionalized magnetic nanoparticles were used in the present study to immobilize MalPase for the efficient synthesis of glucose-1-phosphate from maltodextrin and phosphate.

\section{Experimental}

\subsection{Cloning, expression, and preparation of the enzyme}

The malpase gene was amplified from E. coli K12 (Escherichia coli) genomic DNA in a $20 \mu 1 \mathrm{PCR}$ reaction using forward $5^{\prime}$-ctggatccatgtcacaacctattttaacg-3' and reverse $5^{\prime}$-cttgcggecgcttagcgttttgcetgccag-3' primers [18]. After purification, the target gene was inserted into the linearized pET24a $(+)$ vector with T4 DNA polymerase. Standard methods for molecular cloning were used [19]. E. coli BL21 (DE3) containing exogenous recombinant plasmids were grown in LB medium (tryptone $10 \mathrm{~g} / \mathrm{L}$, yeast extract $5 \mathrm{~g} / \mathrm{L}$ 
and $\mathrm{NaCl} 10 \mathrm{~g} / \mathrm{L}$ ) at $37^{\circ} \mathrm{C}$ with shaking at $200 \mathrm{r} / \mathrm{min}$. When the $\mathrm{OD}_{600}$ of the culture broth reached about $0.7,0.05 \mathrm{~mol} / \mathrm{L}$ IPTG (isopropyl- $\beta$-D-Thiogalactoside) was added and the cultivation temperature was reduced and kept at $15{ }^{\circ} \mathrm{C}$ with shaking at $120 \mathrm{r} / \mathrm{min}$ for $20 \mathrm{~h}$ to induce the expression of the target enzyme protein. The cells were then harvested by centrifugation at $12000 \times g$ for $10 \mathrm{~min}$ at $4{ }^{\circ} \mathrm{C}$ followed by disruption using ultrasonication $(400 \mathrm{~W})$. The ultrasonication process lasted for 100 cycles. Each cycle included $4 \mathrm{~s}$ of sonication and a $6 \mathrm{~s}$ pause. After centrifugation the supernatant was collected and lyophilized forming a crude enzyme powder.

\subsection{Activity assays}

The diluted sample was mixed with $1 \mathrm{ml}$ of a solution containing 5\% maltodextrin, $2 \mathrm{mmol} / \mathrm{L}$ UTP, $10 \mathrm{mmol} / \mathrm{L}$ $\mathrm{MgCl}_{2}, 1 \mathrm{mg}$ maltodextrin phosphorylase, $0.25 \mathrm{U}$ glucose-1-phosphate thymidylytransferase, and $0.5 \mathrm{U}$ pyrophosphatase in $100 \mathrm{mmol} / \mathrm{L}$ PBS (sodium phosphate buffer) $(\mathrm{pH} 7.5)$. The reaction was allowed to proceed for $60 \mathrm{~min}$ and then the samples were frozen at $-20{ }^{\circ} \mathrm{C}$. The yield of UDP-glucose (uridine diphosphate glucose) was measured by HPLC. Chromatography was performed on a Shimadzu system (LC-10ADVP) equipped with an Agela $\mathrm{SAX} \mathrm{\textrm {NH } _ { 2 }}$ column $(150 \mu \mathrm{m}, 4.6 \times 150 \mathrm{~mm})$ using isocratic elution with $67 \mathrm{mmol} / \mathrm{L} \mathrm{Na} \mathrm{HPO}_{4}-\mathrm{KH}_{2} \mathrm{PO}_{4}(\mathrm{pH} \mathrm{5.3}$ ). The flow rate was $1.5 \mathrm{ml} / \mathrm{min}$ and UV detection was carried out at $260 \mathrm{~nm}$ [8]. One unit of MalPase activity was defined as the amount of enzyme producing $1 \mu \mathrm{mol}$ of UDP-glucose within $1 \mathrm{~min}$ under the described conditions.

Glc-1-P was identified and quantified by ion chromatography (IC) using an ICS-1500 ion chromatography system with a Ion Pac AS11-HC (4 mm $\times 250 \mathrm{~mm})$ analytical column. Elution was carried out with a $12 \mathrm{mmol} / \mathrm{L} \mathrm{NaOH}$ solution at a flow rate of $1 \mathrm{ml} / \mathrm{min}$ at $30{ }^{\circ} \mathrm{C}$.

\subsection{Immobilization of the enzyme}

Amino-functionalized magnetic particles $(10 \mathrm{mg} / \mathrm{ml})$ were suspended in PBS (50 mmol/L, $\mathrm{pH} \mathrm{7.5)}$ and then ultrasonicated for $20 \mathrm{~min}$. Thereafter, $25 \%$ glutaraldehyde (20 $\mu \mathrm{l} / \mathrm{ml}$ ) was added and shaken for $12 \mathrm{~h}$ at $30{ }^{\circ} \mathrm{C}$ and 1100 $\mathrm{r} / \mathrm{min}$. The nanoparticles were then separated by magnetic decantation and washed five times with PBS (50 mM, pH 7.5) to eliminate the excessive unreacted glutaraldehyde. The MalPase solution was mixed with the amino-functionalized magnetic nanoparticles and shaken at $30^{\circ} \mathrm{C}$ for 30 $\mathrm{min}$ at $1100 \mathrm{r} / \mathrm{min}$. After this reaction period, the nanoparticles were separated by magnetic decantation and washed five times with PBS $(50 \mathrm{mmol} / \mathrm{L}, \mathrm{pH} 7.5)$ to remove any unbound enzymes. The MalPase binding efficiency is de- fined as:

$$
E=\left(C_{1}-C_{0}\right) / C_{1}
$$

where $E$ is the MalPase binding efficiency, and $C_{1}$ and $C_{0}$ are the amounts of MalPase protein in the solution before and after immobilization, respectively. The activity recovery of the immobilized MalPase was calculated as follows:

$$
R=A /\left(A_{1}-A_{0}\right)
$$

where $R$ is the activity recovery of the immobilized MalPase, $A$ is the activity of the immobilized MalPase, and $A_{1}$ and $A_{0}$ are the activity of the free MalPase in solution before and after immobilization respectively.

\subsection{Comparison between the free and immobilized MalPases}

The effects of $\mathrm{pH}$ on the initial reaction rate of free and immobilized MalPase were determined at various $\mathrm{pH}$ (ranging from 6.5 to 8.5). The apparent kinetic parameters $K_{\mathrm{m}}$ and $V_{\max }$ of the free and immobilized MalPase were determined at $30{ }^{\circ} \mathrm{C}$ by measuring the initial reaction rate by the method described above. $K_{\mathrm{m}}$ and $V_{\max }$ were calculated from Lineweaver-Burk plots according to the following formula:

$$
1 / V=K_{\mathrm{m}} / V_{\max } \cdot C_{\mathrm{s}}+1 / V_{\max }
$$

where $V$ is the initial rate of reaction at different maltodextrin concentrations or phosphate concentrations $C_{\mathrm{S}}, K_{\mathrm{m}}$ is the Michaelis constant, and $V_{\max }$ is the maximum reaction rate.

\subsection{Reuse of immobilized MalPases and purification of Glc-1-P}

A $200 \mathrm{ml}$ reaction mixture in a 500-ml narrow neck flask containing $5 \mathrm{~g} / \mathrm{L}$ maltodextrin in $100 \mathrm{mmol} / \mathrm{L}$ PBS (pH 7.5) was combined with immobilized MalPase for the synthesis reaction. The product concentration was analyzed periodically by HPLC. After one batch of reactions, the immobilized enzyme was recovered through magnetic separation. The recovered immobilized enzyme was washed thrice with PBS (100 mmol/L, pH 7.5) and reused in a new reaction with fresh substrate. To isolate Glc-1-P, the reaction mixture was collected after removing the immobilized enzymes. The $\mathrm{pH}$ of the mixture was adjusted to 4.2 with $\mathrm{H}_{3} \mathrm{PO}_{4}$ and an equivalent volume of methanol was added. The mixture was deposited at $4{ }^{\circ} \mathrm{C}$ for $15 \mathrm{~min}$. The supernatant was then collected after centrifugation at $9000 \times g$ for 5 min at $4{ }^{\circ} \mathrm{C}$ and it was concentrated by rotary evaporation at $50{ }^{\circ} \mathrm{C}$. After the $\mathrm{pH}$ of the concentrated solution was adjusted to 8 using $\mathrm{NaOH}$, Glc-1-P was precipitated by the addition of three times the volume of ethanol. The precipitates were collected after centrifugation at $9000 \times \mathrm{g}$ for $20 \mathrm{~min}$ at $4{ }^{\circ} \mathrm{C}$ and vacuum dried at $30{ }^{\circ} \mathrm{C}$. The purity of Glc-1-P was analyzed by 
HPLC using the method described above and the product was characterized by mass spectrometry (MS).

\section{Results and discussion}

Recombinant MalPase was expressed after IPTG induction. Although the conditions of induction were optimized, SDS-PAGE revealed that the insoluble fraction was more than $80 \%$ of the whole cell recombinant MalPase. It showed a protein with a molecular weight identical to the predicted value of $88 \mathrm{kDa}$ (kilodalton) [20]. After immobilization on the amino-functionalized magnetic nanoparticles, $85.8 \%$ of the original activity of the recombinant MalPase was retained. The MalPase binding efficiency was $47.5 \%$ and the enzyme loading was $47.5 \mathrm{mg} / \mathrm{g}$. The specific activity of the immobilized MalPase was $5.66 \mathrm{U} / \mathrm{g}$.

Figure 1 shows a comparison between the free and immobilized MalPase in response to the external $\mathrm{pH}$. The overall trends of activity were similar for both the free and immobilized MalPase. However, the immobilized MalPase appeared to be more stable against $\mathrm{pH}$ changes than the free MalPase.

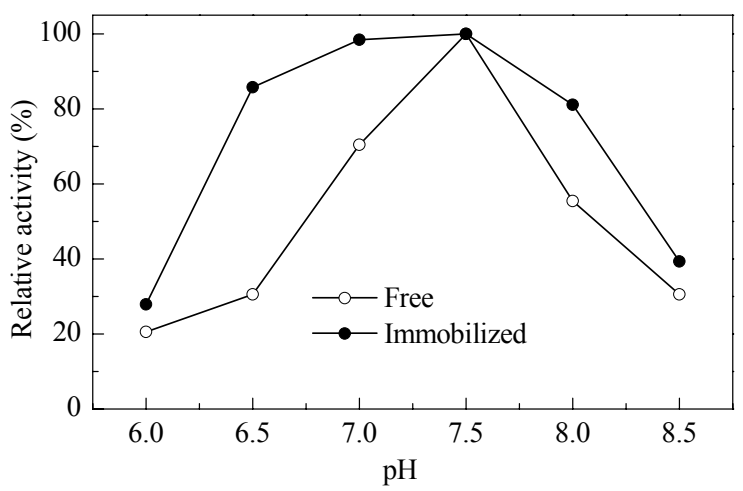

Fig. 1. Effect of $\mathrm{pH}$ on initial activity of free and immobilized MalPase.
The kinetic behavior of the free and immobilized MalPase was examined at different maltodextrin and phosphate concentrations. The apparent Michaelis constant $K_{\mathrm{m}}$ and the maximum reaction rate $V_{\max }$ are presented in Table 1. After immobilization, the $K_{\mathrm{m}}$ value of MalPase toward maltodextrin increased 1.5 times whereas that toward phosphate increased 1.7 times compared with the free enzyme. This indicated some resistance from the carrier toward the interaction between the substrate and the enzyme. The $V_{\max }$ values of the immobilized MalPase were almost 3.2-times (toward maltodextrin) and 3.4-times (toward phosphate) higher than those of the free enzyme. The immobilization of the enzyme might have caused a variation in its enzyme kinetic behavior. This suggests an improvement in the efficiency of Glc-1-P production when it is catalyzed using immobilized MalPase rather than using the free enzyme in a homogeneous solution.

Table 1 Kinetic parameters of the free and immobilized MalPases toward maltodextrin and phosphate

\begin{tabular}{lccccc}
\hline \multirow{2}{*}{ Enzyme } & \multicolumn{2}{c}{$K_{\mathrm{m}} /(\mathrm{mmol} / \mathrm{L})$} & & \multicolumn{2}{c}{$V_{\max } /(\mu \mathrm{mol} /(\mathrm{min} \cdot \mathrm{mg}))$} \\
\cline { 2 - 3 } \cline { 5 - 6 } & Maltodextrin & Phosphate & & Maltodextrin & Phosphate \\
\hline Free & 39.5 & 23.2 & & 7.2 & 9.0 \\
Immobilized & 59.5 & 40.0 & & 23.0 & 30.9 \\
\hline
\end{tabular}

The substrate concentration was optimized in $1.5 \mathrm{ml}$ tubes (Eppendorf SafeLock). Figure 2 shows that an increase in the maltodextrin concentration did not increase the production rate of Glc-1-P. This was due to a high concentration of maltodextrin leading to a viscous reaction system and to aggregation of the immobilized enzyme. The most suitable concentration of phosphate in this reaction system was found to be $100 \mathrm{mmol} / \mathrm{L}$ (Fig. 2). We assumed that an excessively high concentration of salt might cause enzyme deactivation by destroying its hydration layer.

Figure 2 also shows the effect of immobilized enzyme loading. An optimal Glc-1-P production was achieved with

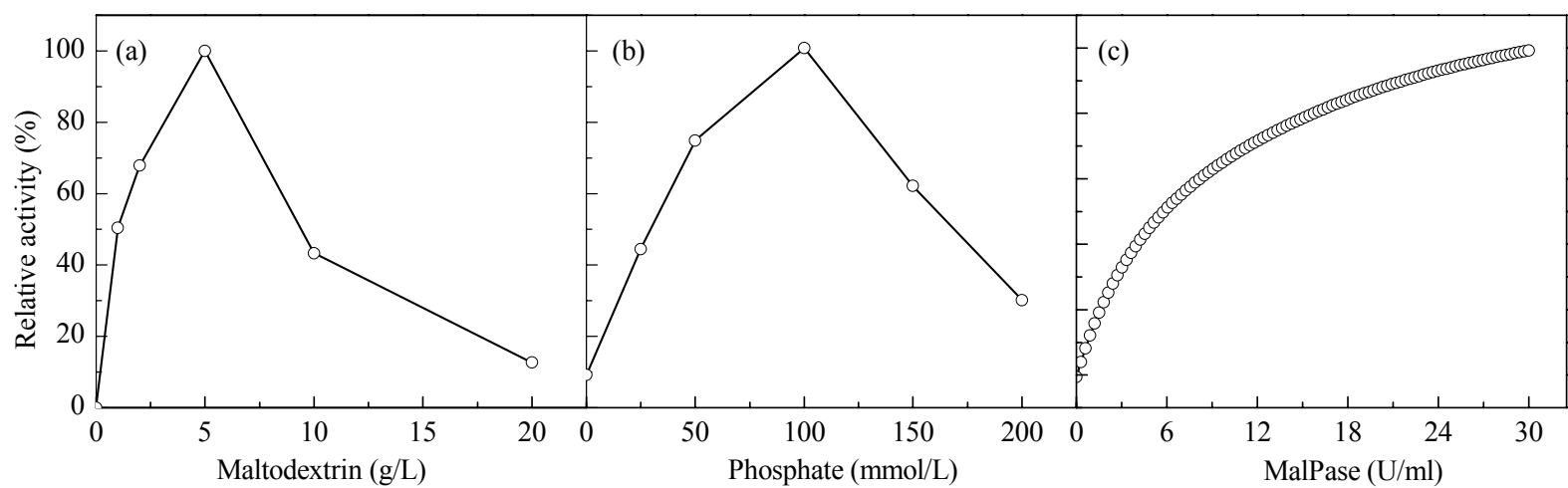

Fig. 2. System optimization for Glc-1-P production. (a) Effect of maltodextrin; (b) Effect of phosphate; (c) Optimization of the immobilized MalPase loaing. Reaction conditions: (a) MalPase $6 \mathrm{mU} / \mathrm{ml}$, PBS (pH 7.5) $50 \mathrm{mmol} / \mathrm{L}, 30^{\circ} \mathrm{C}, 4 \mathrm{~h}$; (b) MalPase $6 \mathrm{mU} / \mathrm{ml}$, maltodextrin $5 \mathrm{~g} / \mathrm{L}$, PBS (pH 7.5 $200 \mathrm{mmol} / \mathrm{L}, 30{ }^{\circ} \mathrm{C}, 4 \mathrm{~h}$; (c) maltodextrin $5 \mathrm{~g} / \mathrm{L}$, PBS (pH 7.5) $100 \mathrm{mmol} / \mathrm{L}, 30^{\circ} \mathrm{C}, 4 \mathrm{~h}$. The relative activity is defined as $R=\left(C_{\mathrm{M}}-C_{0}\right) / C_{\mathrm{M}}$, where $R$ is relative activity, $C_{\mathrm{M}}$ is the optimal condition yield for Glc-1-P, and $C_{0}$ is the yield of specific conditions for Glc-1-P. 
$24 \mathrm{mU} / \mathrm{ml}$ of immobilized MalPase. When the load of immobilized enzyme was increased further, the product concentration became saturated. The excess heavy support in the system may hamper the free movement of the immobilized enzyme.

The time course of Glc-1-P production was examined and is shown in Fig. 3. The concentration of Glc-1-P did not markedly increase after transformation by the immobilized enzymes over about $8 \mathrm{~h}$.

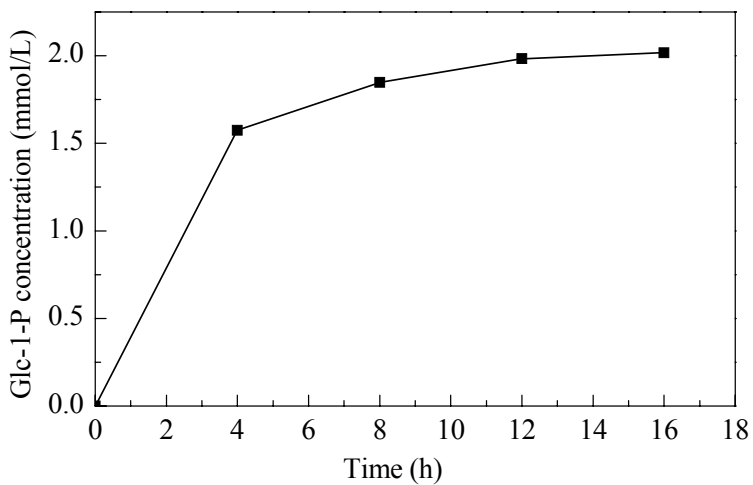

Fig. 3. The time-course for Glc-1-P synthesis by immobilized MalPase. Reaction conditions: MalPase $6 \mathrm{mU} / \mathrm{ml}$, maltodextrin $5 \mathrm{~g} / \mathrm{L}$, PBS (pH 7.5) $50 \mathrm{mmol} / \mathrm{L}, 30^{\circ} \mathrm{C}$.

The optimal reaction conditions for Glc-1-P synthesis by the immobilized MalPase were: MalPase, $24 \mathrm{mU} / \mathrm{ml}$; maltodextrin, $5 \mathrm{~g} / \mathrm{L}$; phosphate buffer, $100 \mathrm{mmol} / \mathrm{L}, \mathrm{pH} 7.5$; temperature $30^{\circ} \mathrm{C}$ and duration $8 \mathrm{~h}$.

After optimization of the reaction conditions, the reaction was carried out in a $200 \mathrm{ml}$ system for the gram-scale preparation of Glc-1-P. After the first batch of reactions, the immobilized enzyme was recovered with a magnet and reused over eight cycles. As shown in Fig. 4, the Glc-1-P yield decreased gradually with an increase in the number of repeat reactions (1-4 batches). Subsequently, we extended the time for each run to $12 \mathrm{~h}$ to obtain higher yields $(5-8$

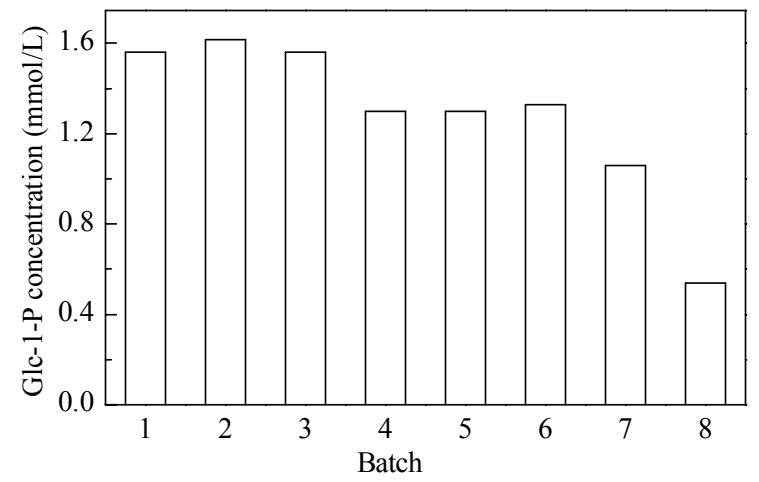

Fig. 4. Repeated batch production of Glc-1-P with recycled immobilized MalPase. Reaction conditions: MalPase $24 \mathrm{mU} / \mathrm{ml}$, maltodextrin $5 \mathrm{~g} / \mathrm{L}$, PBS (pH 7.5) $100 \mathrm{mmol} / \mathrm{L}, 30^{\circ} \mathrm{C}$, total volume $200 \mathrm{ml}$. batches). However, in the eighth reaction the yield was not at the same level as that of the previous batches. After eight consecutive reactions (about $96 \mathrm{~h}$ in total) the immobilized MalPase still retained some activity. This indicates that the covalently immobilized enzyme was quite stable on the magnetic nanoparticles.

The supernatants of the eight batches of reactions were combined and concentrated, and the concentrate was purified as described earlier. A white solid of about $440 \mathrm{mg}$ was obtained after vacuum drying. The isolated yield of the product was $70.5 \%$. The final product was characterized by LC-MS. The MS results showed peaks at 263.21 $[\mathrm{M}+\mathrm{Na}+\mathrm{H}]^{+}, 299.16[\mathrm{M}+\mathrm{Ka}+\mathrm{H}]^{+}$, and $305.27[\mathrm{M}+2 \mathrm{Na}+\mathrm{H}]^{+}$, which were consistent with the calculated values.

\section{Conclusions}

A gram-scale synthesis of glucose-1-phosphate from low-cost maltodextrin was achieved through repeat batch reactions using a recyclable biocatalyst. The biocatalyst was prepared using a recombinant maltodextrin phosphorylase cloned from $E$. coli $\mathrm{K} 12$, which was covalently immobilized onto amino-functionalized magnetic nanoparticles. The immobilized MalPase was operationally stable and reusable, retaining high catalytic activity in repeat reactions. The product was purified by simple precipitation and centrifugation. The free and immobilized enzyme as well as the unspent substrates and organic solvent for purification were recovered efficiently. Therefore, this method of generating Glc-1-P is extremely cost-effective. The reaction system described in this study has great potential for the practical production of high-value-added Glc-1-P or other glucose monophosphates.

\section{References}

1 Goedl C, Schwarz A, Minani A, Nidetzky B. J Biotechnol, 2007, 129: 77

2 Biggins J B, Onwueme K C, Thorson J S. Science, 2003, 301: 1537

3 Wong C H. Carbohydrate-Based Drug Discovery. Weinhein: Wiley-VCH. 2003

4 Thorson J S, Barton W A, Hoffmeister D, Albermann C, Nikolov D B. ChemBioChem, 2004, 5: 16

5 Griffith B R, Langenhan J M, Thorson J S. Curr Opin Biotechnol, 2004, 16: 622

6 Schinzel R, Nidetzky B. FEMS Microbiol Lett, 1999, 171: 73

7 Nahálka J, Shao J, Gemeiner P. Biotechnol Appl Biochem, 2007, 46: 1

8 Nahálka J. J Ind Microbiol Biotechnol, 2007, 35: 219

9 Chen S Q, Liu J F, Pei H D, Li J, Zhou J, Xiang H. Enzyme Microb Technol, 2007, 41: 390 
10 Hong Y, Wu L, Liu B, Peng C, Sheng D H, Ni J F, Shen Y L. J Mol Catal B, 2008, 54: 27

11 Bae J, Lee D H, Kim D, Cho S J, Park J E, Koh S, Kim J, Park B H, Choi Y, Shin H J, Hong S I, Lee D S. Process Biochem, 2005, 40: 3707

12 Hu B, Pan J, Yu H L, Liu J W, Xu J H. Process Biochem, 2009, 44: 1019

13 Li Y G, Gao H S, Li W L, Xing J M, Liu H Z. Bioresour Technol, 2009, 100: 5092

14 Yong Y, Bai Y X, Li Y F, Lin L. Process Biochem, 2008, 43: 1179
15 Zhu H, Pan J, Hu B, Yu H L, Xu J H. J Mol Catal B, 2009, 61: 174

16 Garg S, Kumar A. Afr J Biotechnol, 2007, 6: 2715

17 Garg N, Kumar A. J Braz Chem Eng, 2008, 25: 229

18 Nora A C, David D, Alejandro M V, Francisco J M, Edurne B F, Marĺa T M Z, Gustavo E, Steven B, Javier P R. J Bacteriol, 2006, 188: 77

19 Sambrook J, Russell D. Molecular Cloning 3. Woodbury: Cold Spring Harbor Laboratory Press, 2001

20 Dong Q, Ouyang L M, Yu H L, Xu J H, Lin G Q. Tetrahedron Lett, 2009, 51: 1603 